\title{
The Pricing of Experience Goods: The Example of en primeur Wine
}

\section{Héla Hadj Ali and Céline Nauges}

The market for "primeur" wine in the Bordeaux region allows producers to sell wine that is still in barrels. As with all experience goods, producers send quality signals to uninformed buyers. Using original data on Bordeaux wines, we show that the pricing behaviour of producers depends to a large extent on their reputation, and much less on short-term changes in quality (as measured by experts' grades). We also find that the primeur price has an informative role, since a 10 percent increase in primeur price leads to a 3 percent increase in prices on the market for bottled wine.

Keywords: Bordeaux wine, experience good, panel data, quality signal, reputation.

Suggested running head: The pricing of en primeur wine

While writing this article, Héla Hadj Ali was working as a research fellow at INRA (National Institute for Research in Agriculture), Toulouse (France). Céline Nauges is a senior research fellow at INRA, Toulouse (France).

The authors wish to thank Pierre Dubois, Valérie Meunier, Katrin Millock, Michel Simioni, Alban Thomas, Ian M. Sheldon (the editor), Michael Visser, and two anonymous reviewers for their useful comments and suggestions that materially improved the article. The usual caveats apply. 
Most food products can be classified as experience goods (Nelson 1970; 1974) because their quality can rarely be ascertained before actual consumption. ${ }^{1}$ A substantial part of the theoretical literature dealing with experience goods has focused on sellers' activity to inform consumers in their purchases, particularly the role of signaling and reputation. Prices, advertising expenditure (Milgrom and Roberts 1986) and warranties (Grossman 1981) are textbook illustrations of how a monopolist can signal the high quality of his product in a game with asymmetric information. Shapiro (1983) emphasized the role of reputation in a perfectly competitive environment by describing how consumers form rational expectations on the quality of experience goods based on the quality of goods produced in the past.

In the particular case of food products, producers often choose labeling as a signal of quality. Bureau and Valceschini (2003) showed that labeling helps promote differentiated products and allows small producers to benefit from a well-established collective reputation. More generally, the use of food labels is said to create the potential for price premia (Henneberry and Armbruster 2003).

Quantitative measures of these "price premia” are quite rare, as well as, more generally, analyses of the pricing strategy and signaling activity of producers in markets for food products. This is especially the case when compared with hedonic studies that measure the consumers' assessment of food product attributes (see McCluskey and Loureiro 2003, for a review). This article contributes to the empirical literature on experience goods by analysing the pricing behaviour of wine producers from the well-known Bordeaux region in France.

Original data on two markets (for "primeur” wine and for bottled wine) provide a unique opportunity to obtain new insights on the pricing strategy of producers. Primeur sales refer to a wine sold several months after the harvest, while it is still in barrels. ${ }^{2}$ At the time of primeur sales, the price of the wine (produced by the château for a particular vintage) is chosen by each individual producer. We assume that this primeur price depends on the 
reputation of the château as well as on short-term changes in quality due to the climatic conditions that prevailed during the grape-growing season. Reputation involves the wine maker's know-how, which is measured, according to Shapiro (1983) and Tirole (1996), by the quality of the wine produced by the château in the past. It is still an open question how much of the producers' market power is driven by reputation rather than short-term changes in quality.

The wine sold "en primeur" is released onto the market for bottled wines a few months after the primeur sales. We might argue that primeur price could be used by the producers as a signal of wine quality on the market for bottled wine. If this hypothesis were correct, i.e., if consumers are expected to look for a signal on wine quality through primeur pricing, then producers might set wine prices accordingly.

In this study, we first separate the effects of reputation and short-term changes in quality, using an analysis of primeur prices to assess their respective impacts on the pricing strategy of producers. Secondly, we estimate the effect of the information content of the primeur price on the price of bottled wine. We distinguish between reputation based on expert grading of wine from previous vintages and “rank”-reputation derived from the quality-based rank of the wine itself. The quality-based classification for Bordeaux wines, which is region-specific, provides information both on the geographical origin and the rank of the wine inside the region. ${ }^{3}$ The labeling system aims to allow producers to certify certain claims about the wine production process. Among other things, it guarantees that the grapes are produced in a delimited region and sets the maximum yield allowed per unit area of land.

Using an unbalanced panel data set of 1,153 wines produced by 132 Bordeaux châteaux over fifteen vintages, we find evidence of a large and significant "reputation premium” mainly driven by the rank of the château in the classification system. In other words, the pricing behaviour of the châteaux during primeur sales, and hence their relative 
market power, depends largely on the reputation driven by the quality-based rank, and to a much lesser extent on the reputation driven by past quality scores. We also find that shortterm changes in wine quality had a very limited influence on the price set by the producers. The analysis showed that a 10 percent increase in primeur prices increases subsequent prices on the market for bottled wine by around 3 percent.

The high reputation premium that we estimate on the sub-sample of Bordeaux producers provides empirical evidence that the use of food labels may give rise to price premia (Henneberry and Armbruster 2003). It also provides empirical support to the statement that the labeling system in European wine markets "has proven successful in guaranteeing a good reputation for many European wines and relatively high profits for the producers” (Giraud-Héraud, Soler, and Tanguy 2002; Marette and Zago 2003). Our results also help understand why European wine producers from famous regions such as Bordeaux are against the idea of moving from the current system of wine labeling to a differentiation system based on grape variety as carried out in countries such as Australia, Chile, South Africa, and the United States. If there were no longer any labeling system promoting reputation, then producers would have to engage in costly marketing policies in order to be able to compete with (much larger) producers from the New World wine countries (Giraud-Héraud, Soler, and Tanguy 2002). ${ }^{4}$

Our study also contributes to the literature on wine markets. Existing studies are mostly concerned with hedonic analyses on bottled wine (for a review, see Lecocq and Visser 2006). The main findings of these previous studies are qualitatively very similar to the results obtained here. Previous authors agree on the larger impact of objective characteristics (vintage and region) and reputation (as measured by rank) on wine price. However, they also find a moderate influence of current quality (as measured by expert grading or sensory characteristics). 


\section{Reputation and Quality in the Pricing of Primeur Wine}

Wine prices are set by producers before the opening of the primeur market. We assume that sellers know the future quality of their wine at the time of primeur sales and that market conditions are such that primeur prices truly reflect information on quality, i.e., the market is not susceptible to the "lemons” problem as discussed by Akerlof (1970). A sufficiently high fraction of informed buyers acting in the market eliminates the lemons problem (Mahenc 2004), which we assume to be the case for the Bordeaux primeur market. Furthermore, potential buyers are assumed not to be fully informed about wine quality, since wine is not yet finished at the time of primeur sales. Potential buyers are thus supposed to form quality expectations using information such as the climatic conditions that prevailed during the grapegrowing season and the reputation of the château. Reputation is defined as the quality of the wine produced in the past (see Shapiro 1983, and Tirole 1996), which we measure by grades attributed to the château for previous vintages and the quality-based rank of the wine. Grades are publicly available through numerous guides and reviews such as the Revue $d u$ Vin de France or the annual "Bordeaux" issue of Wine Spectator, the largest circulation U.S. wine magazine.

Bordeaux wine has been ranked since the nineteenth century within defined geographical areas (so-called regions). There are three ranking systems currently in use for Bordeaux reds (for a summary, see table 1).

1. The first ranking for wines from the Médoc dates back to 1855, and is largely unchanged to this day. ${ }^{5}$ Wines were classified following a five-tier classification system ranging from topquality Premiers Crus or First Growth (denoted here as ME-1) to Cinquièmes Crus or Fifth 
Growth (ME-5). Later on, in 1920, some of the non-ranked châteaux were classified in a sixth group called Crus Bourgeois (ME-6).

2. Saint Emilion wines, formally classified in 1955 (subsequently revised every ten years), follow a three-tier ranking system: Premiers Grands Crus Classés A (SE-1), Premiers Grands Crus Classés B (SE-2), and Grands Crus Classés (SE-3).

3. Wine from the Graves (GR) was officially classified from the beginning of 1953.

[table 1 here]

Our database also contains châteaux belonging to the Pomerol area, which has always refused to rank its own wines.

This region-specific quality-based ranking allows producers to certify that the grapes come from a delimited region and that the yield does not exceed a predetermined level. The quality-based classification thus enhances wine differentiation, which, combined with heterogeneity in wine taste and possible barriers to entry, may drive monopolistic positions and thus provide market power especially to the foremost châteaux (Mahenc and Meunier 2006). In addition to potential market failure due to imperfect competition, the asymmetric information between sellers and buyers is likely to create price distortion. This is because high-quality producers have an incentive to signal the high quality of their wine through the choice of a primeur price (see Shapiro 1983; Mahenc and Meunier 2003; Mahenc 2004). Using theoretical arguments, Mahenc and Meunier (2003) have shown that only high primeur prices can provide an effective signal of high quality since it is more costly to produce highquality than low-quality wine.

Hence, the "primeur” price function should incorporate "current” quality as well as reputation effects, along with some measures of market power and signaling costs. It is 
important to understand that a price function incorporating quality and reputation effects is theoretically consistent with the oligopolistic paradigm, as shown by Shaked and Sutton (1982), Tirole (1996) and Mahenc (2004), among others. The Bordeaux grands crus industry was indeed chosen as an illustration of an oligopolistic market, with two differentiated goods that differ in taste and quality, in Mahenc (2004).

The primeur price function used here for the empirical analysis incorporates measures of quality and reputation, and can be written as:

$$
P_{i t}=P\left(V Q_{t}, W Q_{i t}, L Q_{i t}, R_{i}, P O M_{i}, V I N T_{t}\right)+\mu_{i}+v_{i t},
$$

where $i$ and $t$ are the index for château and vintage, respectively (the observation unit is the wine produced by château i for vintage $t$ ).

Current wine quality is measured by the two variables $V Q_{t}$ and $W Q_{i t}$. The overall vintage quality, as judged by Wine Spectator (see table A1 in Appendix for more details on this particular grade), is denoted as $V Q_{t}$, while wine quality, $W Q_{i t}$, is the grade attributed by Robert Parker (a famous wine expert and editor of The Wine Advocate) to the bottled wine, long after its primeur sales. ${ }^{6}$ The vintage grade from Wine Spectator provides a good approximation of the information on current vintage quality available to consumers during primeur sales. Ashenfelter, Ashmore, and Lalonde (1995) showed that the overall vintage quality was highly correlated with the climatic conditions that prevailed during the growing season. The scores attributed by Robert Parker to each wine measure the expected wine quality at maturity, an item of information that is assumed to be known by the seller at the time of primeur sales. ${ }^{7}$

Reputation is measured by two variables ( $L Q$ and $R$ ), both of which are highly correlated with the quality of the wine produced in the past. $L Q_{i t}$ is the average of lagged 
quality scores, computed for each wine using all the available data. ${ }^{8}$ We tried different model specifications, in particular the quality score given to the wine produced by the château during the last vintage, and an interaction effect between the mean of past quality scores and the rank. The model presented here produces the best fit to our data. $R_{i}$ is a vector of $0 / 1$ variables, which is used to take account of the rank attributed to the wine in the quality-based classification system. We also include a dummy variable for the non-classified wines, which groups together both wines from the Pomerol area and non-classified wines from the Médoc, Saint Emilion and Graves. As discussed above, the rank effect may incorporate both the degree of market power of the château and the signaling cost for high quality. Because of data limitations, we are unable to separate these effects. Indeed, we have no information on the number of bottles sold by each château at primeur sales, which could have been used to build a proxy for the Lerner index. $P O M_{i}$ is a dummy variable indicating whether or not the château belongs to the Pomerol, which is the only area without any ranking system.

Finally, we take advantage of the panel form of the data to specify vintage dummies, $V I N T_{t}$, and unobserved château-specific effects, $\mu_{i}$. Since we use the Wine Spectator's grade to take account of overall vintage quality, the vintage dummies allow us to check for any time-specific effect or market trends that would have affected the pricing behaviour of all producers at the same time. The château-specific effect would reflect some "individual reputation” premium or, equivalently, market power based on the château's name. In particular, we would expect the unobservable château effect to be larger for famous wines belonging to regions without any ranking system (Pomerol in our sample).

We assume a linear relationship between the primeur price and the explanatory variables. The random château effect, $\mu_{i}$, and the usual idiosyncratic error term, $v_{i t}$, are assumed to be uncorrelated, while being independently and identically distributed (i.i.d.) with a normal distribution centred on zero. ${ }^{9}$ 


\section{Data and Estimation Results}

In this study, we use a sample of 132 Bordeaux châteaux that produced red wine between 1983 and 1998, except for the 1984 vintage. ${ }^{10}$ Overall, 1,153 wines are represented in the sample. As the data were provided by one of the most famous broker houses in Bordeaux, they can be considered as fairly representative of the market for Bordeaux wines. Primeur price is defined as the price of a 75-cl bottle in euro equivalent (base 1990).

Prices vary considerably across wines in the data set. Figure 1 shows that the trend in average primeur price matches the experts' judgement up until 1995. This seems to be no longer the case towards the end of the studied period, particularly for the 1997 vintage, which was sold at the highest primeur price despite not being recognized by Wine Spectator as a "good” wine.

[figure 1 here]

Table 2 presents some simple statistics showing that average primeur prices match the ranking hierarchy: within each ranking, the better the rank, the higher the primeur price. In the Médoc classification, for example, the prices of wine belonging to the first-quality group (ME-1) are situated largely above the price of wine classified as lower quality, coming from ME-2 to ME-6. The last column, NC, groups the non-classified wines from the three regions that have adopted a ranking system (Médoc, Saint Emilion, and Graves), and the wines from the Pomerol region where no ranking system exists.

[table 2 here] 
The model fitting the logarithm of the primeur price is estimated using the Generalized Least Squares (GLS) method. We choose the Premiers Grands Crus Classés A from Saint Emilion (SE-1) as the reference for the rank dummies, and 1990 as the baseline vintage year. Table 3 presents the results of this model specification. In addition to estimated coefficients, standard errors, and probability, this table also reports - in the last two columns - the 95 percent confidence interval for the "multiplicative” marginal effects of each variable. Since the primeur price is expressed as a logarithm, taking the exponential of each estimated coefficient gives the multiplicative marginal effect of the corresponding variable (relative to the baseline case when considering dummy variables). For example, the marginal effect of not being classified has a 95 percent probability of lying in the $[0.17,0.35]$ interval, which means that, all other characteristics being equal, a non-classified wine will be priced between 0.17 and 0.35 times the price of a wine ranked as a Premiers Grands Crus Classés A from Saint Emilion.

[table 3 here]

The overall fit of the model is good, since the overall $\mathrm{R}^{2}$ value is 0.76 and most of the variables are significant at the 99 percent level. Although the two measures of current quality (Robert Parker's wine grade and Wine Spectator's grade) prove to be highly significant, their impact on price is nevertheless rather limited as shown by the multiplicative marginal effect, which ranges between 1.00 and 1.02, i.e., a one-point increase in grade has almost no effect on the price set by producers. ${ }^{11}$ The average of past quality scores has an expected positive sign, but its influence on price is also very small. Rank-reputation is found to influence significantly the pricing behaviour of producers: wines belonging to all other ranks apart from the first rank in the Médoc area are priced significantly below wines from rank SE-1 ( the 
baseline rank), according to the hierarchy of ranking in each area (i.e. the estimated effects tend to decrease from ME-2 to ME-6). The multiplicative effects range from 0.13 (ME-6) to 1.22 (ME-1), the latter being non-significant. In other words, if two wines from the same vintage obtain the same grade in Robert Parker's records, one belonging to the top-group of Saint Emilion (SE-1) and the other belonging to the lowest group of Médoc (ME-6), the former will still be priced on the primeur market between five and six times the price of the latter. These results indicate that there is a high reputation premium attached to the famous top ranks in the Médoc and Saint Emilion areas, which could be due to the exercise of market power combined with a signaling cost for high quality.

The decision of the Pomerol châteaux not to establish a quality-based classification explains the high significance of the corresponding dummy variable. The strong positive effect of the Pomerol indicator (the multiplicative marginal effect ranges between 1.26 and 1.87) on the primeur price reflects the market power attached to the name of an area (designation) that produces famous wine such as Château Petrus.

Most of the vintage dummies are highly significant with respect to the 1990 base vintage. All coefficients are positive, showing that the 1990 vintage, even if judged of very good quality, has been priced significantly below vintages of lower quality (see Wine Spectator's grades in table A1 of the Appendix). This last result indicates that market trends significantly influence the choice of primeur prices. In particular, we should note the high coefficients of the 1996 to 1998 dummies (multiplicative effects range from 1.67 to 2.58) when the wine market was flourishing because of the combined effects of the "French Paradox”, the assessment of health benefits from wine consumption, and the emergence of new buyers from Asian countries.

Finally, estimation results show that 69 percent of the unexplained model variance is due to unobservable château effects. The château effect represents the pricing behaviour of a 
château over and above the influence of current quality and rank-reputation (or collective reputation). A positive château effect indicates that the château has some market power provided by its name (individual reputation) and/or is willing to signal high quality by choosing high prices. Unobservable château effects can be identified in this model, while the statistical description may provide some insights about the heterogeneity in the sampled population of châteaux. Analysis of the 132 château effects yields a close-to-normal distribution centred on 0 (see figure A1 in Appendix). Table 4 reports some simple statistics on the château-specific effects.

[table 4 here]

We show that, for some of the châteaux, the unobserved château effect has a large impact on primeur prices. The multiplicative effect is found to range between 0.58 and 2.01, and between 0.86 and 1.15 for 50 percent of the châteaux. On the one hand, the estimated château effects for the five wines belonging to the first-quality ranking in the Médoc area (ME-1) are almost zero, which means that their market power is almost completely captured by the rank dummy. On the other hand, the highest estimated château effects very often correspond to wines produced by famous non-classified châteaux (in particular, famous châteaux from the Pomerol area). These châteaux have some market power driven by their own name (individual reputation), rather than the quality-based rank.

\section{The Informative Role of Primeur Price on Spot Price}

Almost a year after the primeur sales, the wine is bottled and released onto the market. The price of bottled wine, or spot price, is determined by an interaction between producer supply and consumer demand. Consumers' willingness to pay depends on their expectations about 
wine quality. The primeur price, which is assumed to be known by the consumer, might play the role of a quality signal. ${ }^{12}$

In this section, we measure the impact of primeur price on subsequent bottled wine prices, ${ }^{13}$ while checking for the effects of current quality and reputation. If this impact is significant, then it will add to the previous analysis by explaining partly the pricing behaviour of the châteaux at the time of primeur sales. In particular, we attempt to demonstrate that producers might be willing to signal quality on the market for bottled wine through the primeur price.

We use the same panel of 132 châteaux for which we have a five-year series of quarterly spot prices (from June 1996 to July 2000). ${ }^{14}$ Because of large market fluctuations, we consider a de-trended spot price. ${ }^{15}$ We include current quality, as measured by Robert Parker's grade, along with collective reputation through rank dummies and wine age. We specify an age-vintage interaction in the model because the relationship between age and price of bottled wine is found to be nonlinear and vary across vintages. The average lagged quality scores are removed from the model as they prove to be non-significant. We specify a châteauspecific effect and use GLS to estimate the model. The total number of observations is 11,841. Estimation results are presented in table 5.

[table 5 here]

The "goodness of fit" of the model $\left(\mathrm{R}^{2}\right)$ is 0.86 , which means that most of the variation in the price of bottled wine is explained by the selected explanatory variables. The introduction of the primeur price leads to a significant increase in the predictability of spot prices. We show that a 10 percent increase in the primeur price increases the subsequent prices of bottled wine by 3 percent. Taken along with the finding that current quality as 
measured by Robert Parker's ratings also has a very small impact on bottled wine prices, this result reinforces the hypothesis that the primeur price acts as a quality signal for consumers. Moreover, this confirms the general findings of empirical studies on commodity futures markets (see Cox 1976 or Carter 1999, for a review), which show that the forward price conveys some information that increases the predictability of spot prices. However, we should note that primeur sales do not have all the typical features of forward contracts, since there is no guarantee on the quality of the wine that is going to be delivered. ${ }^{16}$

Finally, the impact of ranking is found to be strong, with multiplicative effects ranging from 0.19 (lower bound of the interval for ME-6) to 1.28 (upper bound for ME-1). The chisquare test of equality of the age effect across vintages is rejected at the 1 percent level, indicating that the age premium is not the same across vintages of different quality. However, the impact of age on the price of bottled wine is somewhat limited, in the same range as the impact of quality. Hence, in the case of bottled wine as well, the ranking proves to have the strongest impact on price. This latter result highlights the role of labeling, in contrast with some published studies measuring the impact of food product labeling on consumers’ behaviour. Indeed, Van der Lans et al. (2001) employed a conjoint analysis to show that Protected Designation of Origin (PDO) labels have no direct effect on consumer preferences in the case of olive oil. Bonnet and Simioni (2001), using a mixed logit model of demand to reflect the distribution of consumers’ willingness to pay for labelled cheese (Camembert), demonstrated that consumers did not value the quality signal provided by PDO labels for these French cheeses.

The fraction of unexplained variance due to château-specific effects is now reduced to 38 percent, compared to 69 percent in the primeur price model. The unobserved château effects are almost normally distributed (see figure A2 in the Appendix). Simple statistics show that the range of multiplicative effects is very close to that reported in the case of 
primeur price (see table 6). In this model, the random château effect should be interpreted as the consumer's valuation of the name of the château.

[table 6 here]

\section{Conclusion}

Using a large and representative sample of Bordeaux wines, we show that the pricing behaviour of producers during primeur sales depends largely on their reputation, and particularly on their ranking in the old quality-based classification system. We find that the few Médoc and Saint Emilion châteaux belonging to the top ranks set their primeur wine price significantly above châteaux belonging to the lower ranks. This high premium may be the result of strong market power and/or a high signaling cost. Separate identification of these two effects remains an open area for future research. Previous and current wine quality are found to have a very limited but significant impact on primeur price. Producers also appear to increase primeur prices when the expected demand is high because of a booming wine market.

The second part of the analysis looks at the relationship between spot price and primeur price, with reference to the literature on commodity futures markets. However, we should be cautious about generalizing our results to other futures markets, since primeur sales are informal and there is no guarantee on the quality of wine to be delivered. Nevertheless, our study supports the hypothesis that including primeur price in the spot-price function increases the predictability of spot prices.

Together with the low impact of current quality (and the nil impact of past quality as measured by grades attributed in the past), this result suggests that the consumers' belief about quality is influenced by primeur prices. The price of bottled wine in the spot price 
model, which here represents the valuation of wine by consumers, appears to be significantly driven by rank issues. These results contradict the findings of previous empirical studies on the impact of food product labeling on consumers’ willingness to pay.

In general, the present study provides some empirical evidence that producers can gain price premia by using food labels (Henneberry and Armbruster 2003). We find that the reputation premium - driven by quality-based ranking - is very high in an area such as Bordeaux, which benefits from a long-established reputation in wine making. The "reputation premium” driven by the quality-based classification significantly outweighs any effect driven by objective measures of past quality or the premium associated with short-term changes in current quality. These findings help in understanding why most European producers from famous regions such as Bordeaux are against the idea of abandoning the current labeling system.

It is somewhat surprising that the New World Wine countries choose product differentiation strategies based on names referring to the grape variety used in the production of each particular wine, instead of adopting labeling systems based on place of origin and quality ranks, which have proved to be successful in Europe. However, we argue that a region-specific and quality-based classification will allow producers to gain some reputation premium only in areas (e.g., in Europe) where a long-term reputation for wine making already exists. This argument is reinforced by the current situation observed in the United States: in places where recognition and reputation of a certain quality have increased (Sonoma County or Napa Valley, for example), wineries have started changing their marketing strategies by placing more emphasis on the origin of the product (Loureiro 2003). This analysis was conducted using data covering vintages from 1983 to 1998, a period during which the French wine market was steadily growing. French wine is now facing more and more competition, especially from New World Wine countries. It would be interesting to 
conduct a similar analysis on the market for Bordeaux primeur wine using recent data. We could then measure whether the pricing strategy of Bordeaux producers has changed, and if the price premium driven by reputation is still high in the Bordeaux region. 


\section{References}

Akerlof, G.A. 1970. “The Market for 'Lemons’: Quality Uncertainty and the Market Mechanism.” Quarterly Journal of Economics, 84: 488-500.

Ashenfelter, O., Ashmore, D. and R. Lalonde. 1995. “Bordeaux Wine Vintage Quality and the weather.” Chance, 8: 7-14.

Bonnet, C. and Simioni, M. (2001). “Assessing Consumer Response to Protected Designation of Origin Labeling: a Mixed Multinomial Logit Approach.” European Review of Agricultural Economics, 28: 433-49.

Bureau, J.C., and E. Valceschini. 2003. “European Food-Labeling Policy: Successes and Limitations.” Journal of Food Distribution Research, 34(3): 70-76.

Carter, C.A. 1999. “Commodity Futures Markets: a Survey.” Australian Journal of Agricultural and Resource Economics, 43: 209-47.

Combris, P., Lecocq, S., and M. Visser. 1997. “Estimation of a Hedonic Price Equation for Bordeaux Wine: Does Quality Matter?” Economic Journal, 107: 309-402.

Combris, P., Lecocq, S., and M. Visser. 2000. “Estimation of a Hedonic Price Equation for Burgundy Wine.” Applied Economics, 32: 961-67.

Cox, C. 1976. "Futures Trading and Market Information.” The Journal of Political Economy, 84: $1215-37$.

Darby M., and E. Karni. 1973. "Free Competition and the Optimal Amount of Fraud.” Journal of Law and Economics, 16: 67-88.

Giraud-Héraud, E., Soler, G., and H. Tanguy. 2002. “Concurrence Internationale dans le Secteur Viticole: Quel Avenir au Modèle d'Appellation d'Origine Contrôlée ?” INRA Sciences Sociales, 5-6/01.

Grossman, S.J. 1981. “The Informational Role of Warranties and Private Disclosure about Product Quality.” Journal of Law and Economics, 24: 461-89. 
Hadj Ali, H. and C. Nauges. 2003. "Vente en Primeur et Investissement : une Etude sur les Grands Crus de Bordeaux. ” Economie et Prévision, 159: 93-103.

Henneberry, S.R. and W.J. Armbruster. 2003. “Emerging Roles for Food Labels: Inform, Protect, Persuade.” Journal of Food Distribution Research, 34(3): 62-69.

Jones, G.V. and K.H. Storchmann. 2001. "Wine Market Prices and Investment under Uncertainty: an Econometric Model for Bordeaux Crus Classés.” Agricultural Economics, 26: 115-33.

Keynes, J. M. (1930). A Treatise on Money. Editor: Macmillan, London.

Landon, S. and C.E. Smith. 1997. “The Use of Quality and Reputation Indicators by Consumers: The Case of Bordeaux Wine.” Journal of Consumer Policy, 20: 289-323.

Landon, S. and C.E. Smith. 1998. “Quality Expectations, Reputation and Price.” Southern Economic Journal, 64: 628-47.

Lecocq, S. and M. Visser. 2006. “What Determines Wine Prices: Objective vs. Sensory Characteristics.” Journal of Wine Economics, 1: 42-56.

Loureiro, M.L. 2003. “Rethinking New Wines: Implications of Local and Environmentally Friendly Labels.” Food Policy, 28: 547-60.

Mahenc, P. 2004. "The Influence of Informed Buyers in Markets Susceptible to the Lemons Problem.” American Journal of Agricultural Economics, 86(3): 649-59.

Mahenc, P. and V. Meunier. 2003. “Forward Markets and Signals of Quality.” Rand Journal of Economics, 34: 478-94.

Mahenc, P. and V. Meunier. 2006. “Early Sales of Bordeaux grands crus.” Journal of Wine Economics, 1: 57-74.

Marette, S. and A. Zago. 2003. “Advertising, Collective Action, and Labeling in the European Wine Markets.” Journal of Food Distribution Research, 34(3): 117-26. 
McCluskey, J.J. and L. Loureiro. 2003. “Consumer Preferences and Willingness to Pay for Food Labeling: A Discussion of Empirical Studies.” Journal of Food Distribution Research, 34(3): 95-102.

Milgrom, P. and J. Roberts. 1986. "Price and Advertising Signals of Product Quality.” Journal of Political Economy, 94: 796-821.

Nelson, P. 1970. “Information and Consumer Behavior.” Journal of Political Economy, 78: 311-29.

Nelson, P. 1974. “Advertising as Information.” Journal of Political Economy, 81: 729-54.

Oczkowski, E. 1994. “A Hedonic Price Function for Australian Premium Table Wine.” Australian Journal of Agricultural Economics, 38: 93-110.

Oczkowski, E. 2001. "Hedonic Wine Price Functions and Measurement Error.” The Economic Record, 77: 374-82.

Rao, A. and K.B. Monroe. 1988. “The Moderating Effect of Prior Knowledge on Cue Utilization in Product Evaluations.” Journal of Consumer Research, 15: 253-64.

Shaked, A. and J. Sutton. 1982. "Relaxing Price Competition Through Product Differentiation.” The Review of Economic Studies, 49: 3-13.

Schamel, G. and K. Anderson. 2003. "Wine Quality and Varietal, Regional and Winery Reputations: Hedonic Prices for Australia and New Zealand.” The Economic Record, 79: 357-69.

Shapiro, C. 1983. “Premiums for High Quality Products as Rents to Reputation.” Quarterly Journal of Economics, 98: 659-80.

Tirole, J. 1996. “A Theory of Collective Reputations (with applications to the persistence of corruption and to firm quality).” Review of Economic Studies, 63: 1-22. 
Van der Lans, I.A., Van Ittersum, K., De Cicco, A. and Loseby, M. 2001. “The Role of the Region of Origin and EU Certificates of Origin in Consumer Evaluation of Food Products.” European Review of Agricultural Economics, 28: 451-77.

Zeithaml, V.A. 1988. “Consumer Perceptions of Price, Quality, and Value: A Means-End Model and Synthesis of Evidence.” Journal of Marketing, 52: 2-22. 


\section{Endnotes}

1. Food products are sometimes described as credence goods in the sense of Darby and Karni (1973) (i.e., some product attributes cannot be accurately evaluated even after consumption), for instance, when the production process involves environment-friendly practices.

2. The primeur market takes place every year in Spring, and represents one of the most important events on the Bordeaux market place. This type of sale allows producers to gain "cash-in-hand" before the wine is bottled. At the same time, it enables buyers to acquire rare wine at potential bargain prices, hence attracting more and more financial speculators (see Hadj Ali and Nauges 2003).

3. Bordeaux wines have been ranked in terms of quality-based classifications since the nineteenth century.

4. The European wine industry is highly fragmented. For instance, the average vineyard size in France is less than 2 hectares, compared with 111 hectares in Australia (Marette and Zago 2003).

5. Except for one: the château Haut-Brion, which belongs to the Graves area.

6. Both quality indices rise by unit intervals from a minimum of 50 to a maximum of 100 .

7. In hedonic studies of wine, quality grades given by experts are the most common measure of wine quality, see Oczkowski (1994, 2001), Jones and Storchmann (2001), Schamel and Anderson (2003), or Lecocq and Visser (2006) for a review. In their hedonic analyses of Bordeaux and Burgundy wines, Combris, Lecocq and Visser (1997 and 2000) have shown sensory attributes (such as aroma, body, firmness, etc.) and chemical characteristics (such as acid and sugar levels) to be statistically insignificant.

8. See also Landon and Smith (1997 and 1998) and Oczkowski (2001), who measure reputation through lagged quality scores in their hedonic analyses of bottled wine. 
9. The normal distribution of unobservable château effects is tested graphically in the empirical section.

10. This vintage was removed from the catalogue by the broker.

11. Robert Parker's grade has a small effect on the price chosen by producers, which might seem surprising to wine specialists (since Robert Parker is known to be highly influential on the Bordeaux wine markets). However, we should bear in mind that this coefficient measures the impact of a one-point increase in Parker's grade, all other wine characteristics (vintage and rank) being equal.

12. We do not discuss further consumers’ perception of quality. It is now common knowledge that consumer's perception of quality is a blend formed by information from multiple sources (certification, labeling, brand names, packaging, price, etc.), see Zeithaml (1988) or Rao and Monroe (1988) for related discussions.

13. Primeur price and spot price are clearly linked via arbitrage, which is due to the compensation given by the producers to buyers for accepting the price risk of holding primeur wine of uncertain quality. From our data, there is only one case where the spot price was less than the primeur price, which would be compatible with the Keynesian theory of normal backwardation (Keynes 1930).

14. The broker's catalogue contains market values for wine computed from the prices listed by wholesale wine merchants on the Bordeaux market.

15. We use a quarterly price index calculated from the regression of the logarithm of price on quarter dummies in order to detrend prices.

16. There has been an attempt to create a futures market for fine Bordeaux wines. In September 2001, Euronext, a privately-owned stock exchange created by the merger of the Paris, Brussels and Amsterdam stock markets in 2000, launched WineFex, the first futures 
market for first-quality Bordeaux wines. Winefex did not manage to attract liquidity and was cancelled in November 2003. 
Table 1. The Three Ranking Systems for Bordeaux Reds

\begin{tabular}{ccc}
\hline Médoc & Saint Emilion & Graves \\
\hline ME-1 (5)* & SE-1 (2) & GR (21) \\
ME-2 (14) & SE-2 (11) & \\
ME-3 (14) & SE-3 (55) & \\
ME-4 (10) & \\
ME-5 (18) & \\
& \\
ME-6 (117)
\end{tabular}

Note: * Number of classified châteaux given in brackets. 
Table 2. Average Primeur Price by Rank (Prices in 1990 Euros Equivalent)

\begin{tabular}{|c|c|c|c|c|c|c|c|c|c|c|c|}
\hline & \multicolumn{6}{|c|}{ Médoc } & \multicolumn{3}{|c|}{ Saint Emilion } & \multicolumn{2}{|l|}{ Graves } \\
\hline & {$[\mathrm{ME}-1$} & ME-2 & ME-3 & ME-4 & ME-5 & ME-6] & [SE-1 & SE-2 & SE-3] & [GR] & NC* \\
\hline Mean & 34 & 15 & 10 & 10 & 9 & 7 & 40 & 16 & 11 & 15 & 16 \\
\hline St Dev & 12 & 8 & 2 & 3 & 4 & 2 & 17 & 7 & 5 & 9 & 10 \\
\hline Number of wines & 74 & 150 & 75 & 94 & 125 & 136 & 26 & 85 & 133 & 117 & 138 \\
\hline
\end{tabular}

Note: * NC is for Non-Classified. Number of wines: 1,153. Number of châteaux: 132. 
Table 3. GLS Estimation of Parameters in the Primeur Price Model

\begin{tabular}{|c|c|c|c|c|c|}
\hline \multirow{2}{*}{$\begin{array}{l}\text { Dependent variable: primeur price (log) } \\
\text { Vintage quality }(V Q) \text { - Wine Spectator's grade }\end{array}$} & \multirow{2}{*}{$\begin{array}{l}\text { Coef. } \\
0.019\end{array}$} & \multirow{2}{*}{$\begin{array}{r}\text { Std Err } \\
0.003\end{array}$} & \multirow{2}{*}{$\begin{array}{r}\text { p-value } \\
0.000\end{array}$} & \multicolumn{2}{|c|}{$\begin{array}{l}\text { Marginal effects } \\
\text { [95\% conf. int.] }\end{array}$} \\
\hline & & & & 1.01 & 1.02 \\
\hline Wine quality (WQ) - Parker’s grade & 0.006 & 0.001 & 0.000 & 1.00 & 1.01 \\
\hline Past wine quality $(L Q)$ & 0.013 & 0.002 & 0.000 & 1.01 & 1.02 \\
\hline \multicolumn{6}{|l|}{ Ranking $(R)$} \\
\hline$M E-1$ & -0.169 & 0.186 & 0.364 & 0.59 & 1.22 \\
\hline$M E-2$ & -1.005 & 0.168 & 0.000 & 0.26 & 0.51 \\
\hline$M E-3$ & -1.333 & 0.177 & 0.000 & 0.19 & 0.37 \\
\hline$M E-4$ & -1.351 & 0.174 & 0.000 & 0.18 & 0.36 \\
\hline$M E-5$ & -1.457 & 0.169 & 0.000 & 0.17 & 0.32 \\
\hline$M E-6$ & -1.719 & 0.165 & 0.000 & 0.13 & 0.25 \\
\hline$S E-1$ & . & . & & 1.00 & 1.00 \\
\hline$S E-2$ & -0.889 & 0.178 & 0.000 & 0.29 & 0.58 \\
\hline$S E-3$ & -1.326 & 0.166 & 0.000 & 0.19 & 0.37 \\
\hline GR & -1.067 & 0.170 & 0.000 & 0.25 & 0.48 \\
\hline Non-classified & -1.406 & 0.176 & 0.000 & 0.17 & 0.35 \\
\hline Pomerol designation (POM) & 0.430 & 0.101 & 0.000 & 1.26 & 1.87 \\
\hline \multicolumn{6}{|l|}{ Vintage effects (VINT) } \\
\hline VINT83 & 0.244 & 0.042 & 0.000 & 1.17 & 1.39 \\
\hline VINT85 & 0.245 & 0.028 & 0.000 & 1.21 & 1.35 \\
\hline VINT86 & 0.045 & 0.026 & 0.077 & 1.00 & 1.10 \\
\hline VINT87 & 0.125 & 0.071 & 0.081 & 0.98 & 1.30 \\
\hline VINT88 & 0.091 & 0.026 & 0.001 & 1.04 & 1.15 \\
\hline VINT89 & 0.148 & 0.024 & 0.000 & 1.11 & 1.22 \\
\hline VINT90 & & . & & 1.00 & 1.00 \\
\hline VINT91 & 0.181 & 0.076 & 0.017 & 1.03 & 1.39 \\
\hline VINT92 & 0.081 & 0.072 & 0.264 & 0.94 & 1.25 \\
\hline VINT93 & 0.051 & 0.045 & 0.257 & 0.96 & 1.15 \\
\hline VINT94 & 0.134 & 0.037 & 0.000 & 1.06 & 1.23 \\
\hline VINT95 & 0.125 & 0.022 & 0.000 & 1.08 & 1.18 \\
\hline VINT96 & 0.590 & 0.039 & 0.000 & 1.67 & 1.95 \\
\hline VINT97 & 0.854 & 0.048 & 0.000 & 2.14 & 2.58 \\
\hline VINT98 & 0.590 & 0.028 & 0.000 & 1.71 & 1.91 \\
\hline
\end{tabular}

Fraction of variance due to unobservable effects: 0.69

Total number of observations: 1,153

Total number of châteaux: 132

$\mathrm{R}^{2}: 0.76$ 
Table 4. Château Effects Estimated from Primeur Price Model

\begin{tabular}{lccccccc}
\hline & & & \multicolumn{5}{c}{ Quartiles } \\
& Mean & Std Dev & $25 \%$ & $50 \%$ & $75 \%$ & Min & Max \\
\hline Overall & 0.000 & 0.234 & -0.147 & -0.006 & 0.143 & -0.537 & 0.699 \\
& $(1.00)$ & $(1.26)$ & $(0.86)$ & $(0.99)$ & $(1.15)$ & $(0.58)$ & $(2.01)$ \\
& & & & & & & \\
ME-1 & 0.000 & 0.012 & -0.009 & -0.005 & 0.003 & -0.009 & 0.020 \\
& $(1.00)$ & $(1.01)$ & $(0.99)$ & $(0.99)$ & $(1.00)$ & $(0.99)$ & $(1.02)$ \\
\hline
\end{tabular}

Note: multiplicative effects in brackets. 
Table 5. GLS Estimation of the Relationship Between Primeur Price and Price of

\section{Bottled Wine}

\begin{tabular}{|c|c|c|c|c|c|}
\hline \multirow{2}{*}{$\begin{array}{l}\text { Dependent variable: price of bottled wine }(\log ) \\
\text { Constant }\end{array}$} & \multirow{2}{*}{$\begin{array}{l}\text { Coef. } \\
0.605\end{array}$} & \multirow{2}{*}{$\begin{array}{r}\text { Std Err } \\
0.123\end{array}$} & \multirow{2}{*}{$\begin{array}{r}\mathrm{p} \text {-value } \\
0.000\end{array}$} & \multicolumn{2}{|c|}{$\begin{array}{l}\text { Marginal effects } \\
\text { [95\% conf. int.] }\end{array}$} \\
\hline & & & & 1.44 & 2.33 \\
\hline Primeur price $(\log )$ & 0.309 & 0.013 & 0.000 & $0.28 *$ & $0.33 *$ \\
\hline Wine quality (Parker’s grade) & 0.025 & 0.001 & 0.000 & 1.02 & 1.03 \\
\hline \multicolumn{6}{|l|}{ Ranking } \\
\hline$M E-1$ & -0.001 & 0.124 & 0.995 & 0.78 & 1.28 \\
\hline$M E-2$ & -0.823 & 0.113 & 0.000 & 0.35 & 0.55 \\
\hline$M E-3$ & -1.077 & 0.119 & 0.000 & 0.27 & 0.43 \\
\hline$M E-4$ & -1.147 & 0.118 & 0.000 & 0.25 & 0.40 \\
\hline$M E-5$ & -1.189 & 0.115 & 0.000 & 0.24 & 0.38 \\
\hline$M E-6$ & -1.417 & 0.112 & 0.000 & 0.19 & 0.30 \\
\hline$S E-1$ & . & & . & 1.00 & 1.00 \\
\hline$S E-2$ & -0.860 & 0.120 & 0.000 & 0.33 & 0.54 \\
\hline$S E-3$ & -1.257 & 0.112 & 0.000 & 0.23 & 0.35 \\
\hline$G R$ & -1.081 & 0.114 & 0.000 & 0.27 & 0.42 \\
\hline Non-classified & -1.223 & 0.119 & 0.000 & 0.23 & 0.37 \\
\hline Pomerol designation & 0.302 & 0.067 & 0.000 & 1.19 & 1.54 \\
\hline \multicolumn{6}{|l|}{ Age } \\
\hline Age x VINT83 & 0.022 & 0.001 & 0.000 & 1.02 & 1.03 \\
\hline Age $\times$ VINT85 & 0.025 & 0.001 & 0.000 & 1.02 & 1.03 \\
\hline Age x VINT86 & 0.025 & 0.001 & 0.000 & 1.02 & 1.03 \\
\hline Age x VINT87 & 0.013 & 0.001 & 0.000 & 1.01 & 1.02 \\
\hline Age x VINT88 & 0.024 & 0.001 & 0.000 & 1.02 & 1.03 \\
\hline Age x VINT89 & 0.027 & 0.001 & 0.000 & 1.03 & 1.03 \\
\hline Age $\times$ VINT90 & 0.032 & 0.001 & 0.000 & 1.03 & 1.03 \\
\hline Age $x$ VINT91 & 0.010 & 0.001 & 0.000 & 1.01 & 1.01 \\
\hline Age x VINT92 & 0.006 & 0.001 & 0.000 & 1.00 & 1.01 \\
\hline Age $x$ VINT93 & 0.014 & 0.001 & 0.000 & 1.01 & 1.02 \\
\hline Age x VINT94 & 0.013 & 0.001 & 0.000 & 1.01 & 1.02 \\
\hline Age $\times$ VINT95 & 0.019 & 0.001 & 0.000 & 1.02 & 1.02 \\
\hline Age x VINT96 & 0.001 & 0.001 & 0.159 & 1.00 & 1.00 \\
\hline Age x VINT97 & -0.022 & 0.001 & 0.000 & 0.98 & 0.98 \\
\hline Age x VINT98 & -0.020 & 0.002 & 0.000 & 0.98 & 0.98 \\
\hline Age x Age & 0.000 & 0.000 & 0.000 & 1.00 & 1.00 \\
\hline
\end{tabular}

Fraction of variance due to unobservable effects: 0.38

Total number of observations: 11,841

Total number of châteaux: 132

R-squared: 0.86

Note: * Numbers in italics represent elasticities and not multiplicative effects. 
Table 6. Château Effects Estimated from Spot Price Model

\begin{tabular}{lccccccc}
\hline & & & \multicolumn{5}{c}{ Quartiles } \\
& Mean & Std Dev & $25 \%$ & $50 \%$ & $75 \%$ & Min & Max \\
\hline Overall & 0.000 & 0.235 & -0.159 & -0.015 & 0.136 & -0.476 & 0.719 \\
& $(1.00)$ & $(1.26)$ & $(0.85)$ & $(0.98)$ & $(1.15)$ & $(0.62)$ & $(2.05)$ \\
& & & & & & \\
ME-1 & 0.000 & 0.133 & -0.039 & -0.023 & 0.003 & -0.153 & 0.213 \\
& $(1.00)$ & $(1.14)$ & $(0.96)$ & $(0.98)$ & $(1.00)$ & $(0.86)$ & $(1.24)$ \\
\hline
\end{tabular}

Note: multiplicative effects in brackets. 
Table A1. Wine Spectator's Grades for Vintage Overall Quality

\begin{tabular}{lll}
\hline Vintage year & Ratings & \\
\hline 1983 & 86 & (Good to very good) \\
1985 & 93 & (Outstanding) \\
1986 & 95 & (Classic) \\
1987 & 76 & (Average) \\
1988 & 93 & (Outstanding) \\
1989 & 98 & (Classic) \\
1990 & 97 & (Classic) \\
1991 & 72 & (Average) \\
1992 & 72 & (Average) \\
1993 & 82 & (Good to very good) \\
1994 & 85 & (Good to very good) \\
1995 & 95 & (Classic) \\
1996 & 85 & (Good to very good) \\
1997 & 81 & (Good to very good) \\
1998 & & (Outstanding) \\
\hline
\end{tabular}


Figures

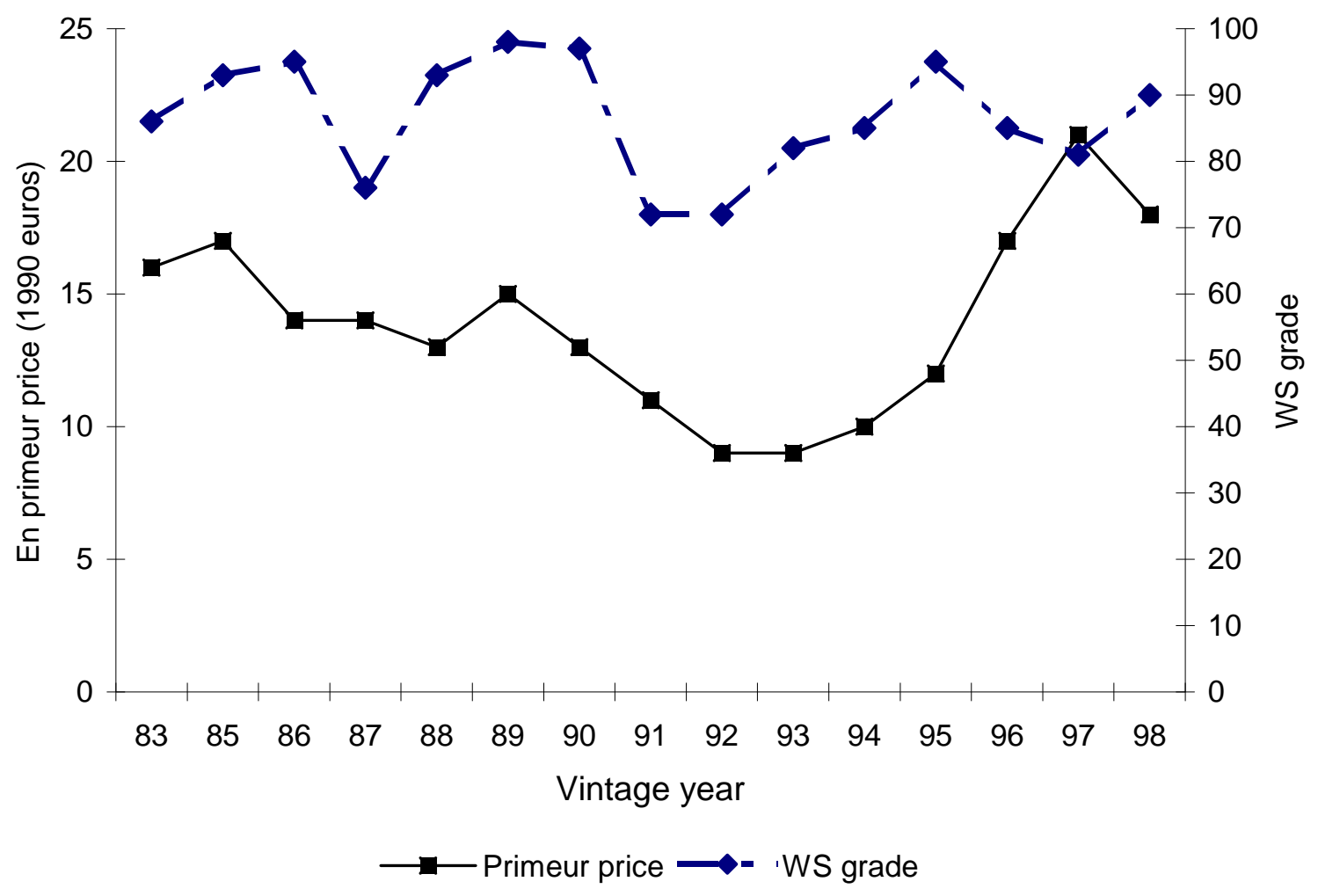

Figure 1. En primeur price and Wine Spectator's grade for 1983 to 1998 vintages 


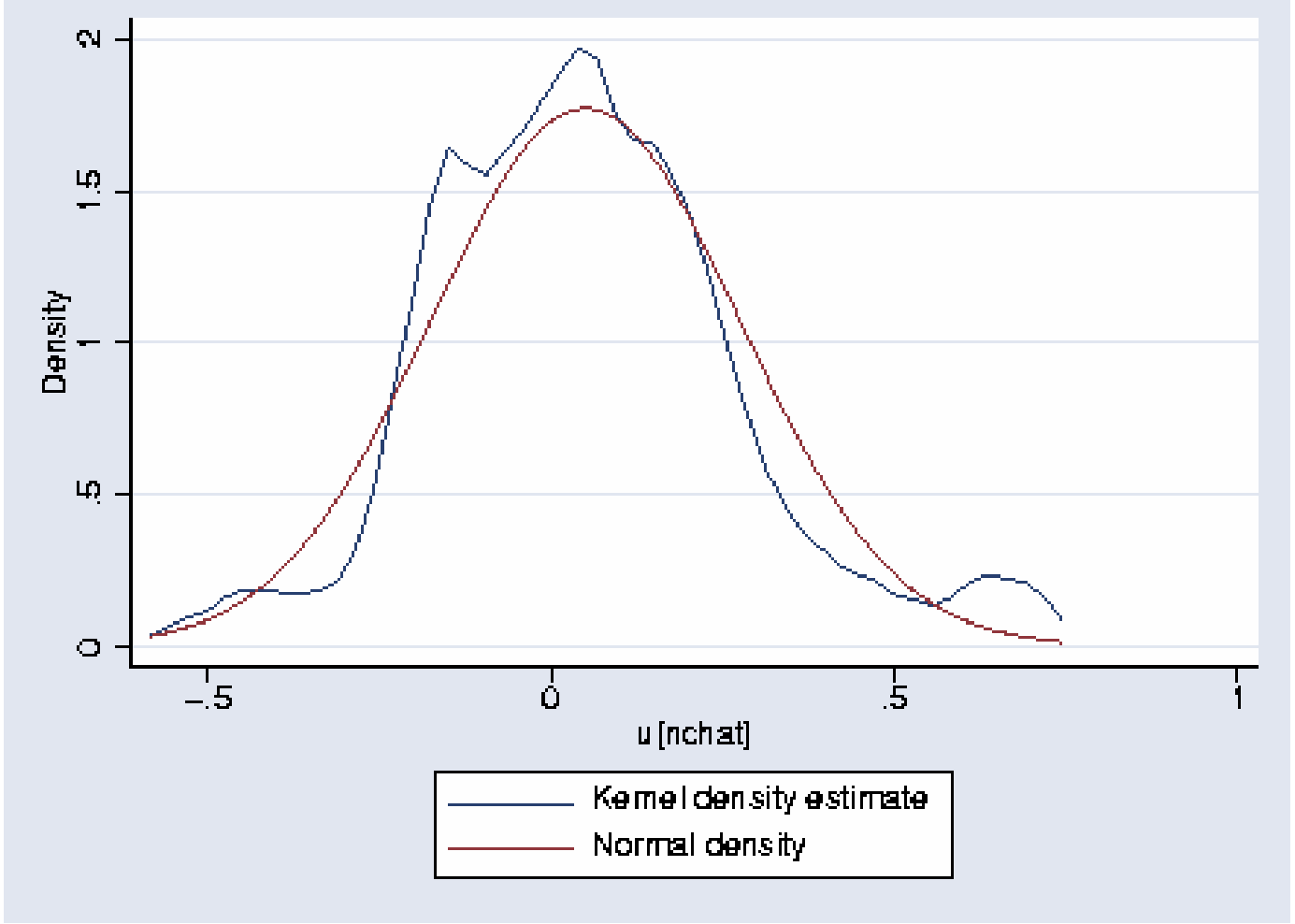

Figure A1. Distribution of estimated château effects - Primeur price model 


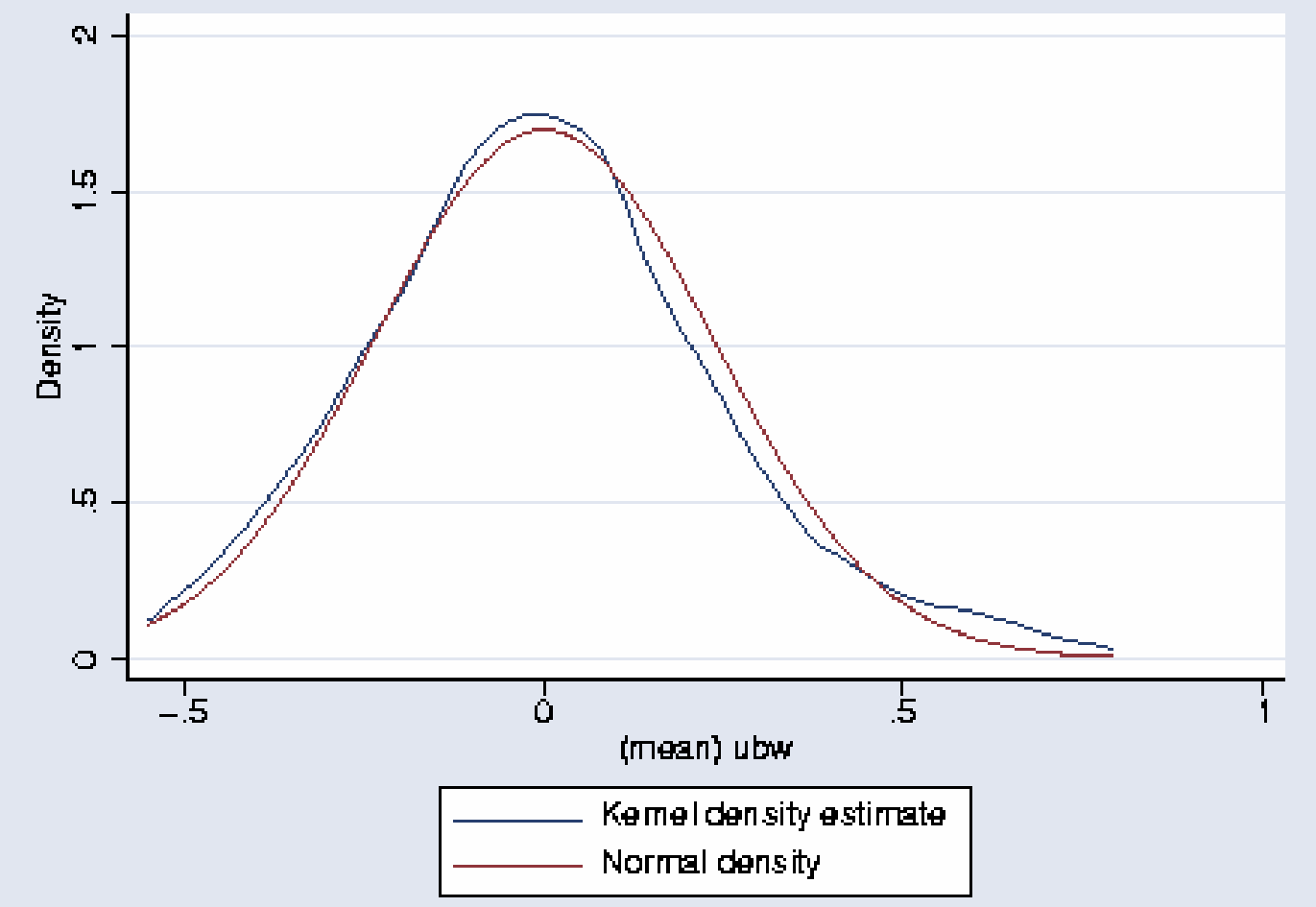

Figure A2. Distribution of estimated château effects - Spot price model 